Review

\title{
The influence of local and landscape scale on single response traits in bees: A meta-analysis
}

\author{
Jeferson Gabriel da Encarnação Coutinho ${ }^{\mathrm{a}, \mathrm{b}, \mathrm{c}, *}$, Lucas Alejandro Garibaldi ${ }^{\mathrm{d}}$, \\ Blandina Felipe Viana ${ }^{\mathrm{a}, \mathrm{c}}$ \\ ${ }^{a}$ Departamento de Zoologia, Instituto de Biologia, Universidade Federal da Bahia, Barão de Jeremoabo Street, CEP 40170-115, Salvador, Bahia, Brazil \\ ${ }^{\mathrm{b}}$ Departamento de Tecnologia em Saúde e Biologia, Instituto Federal de Educação, Ciência e Tecnologia da Bahia, CEP 40301-015, Emidio dos Santos Street, Barbalho, \\ Salvador, Bahia, Brazil \\ ${ }^{\mathrm{c}}$ National Institute of Science and Technology in Interdisciplinary and Transdisciplinary Studies in Ecology and Evolution (INCT IN-TREE) \\ ${ }^{\mathrm{d}}$ Instituto de Investigaciones en Recursos Naturales, Agroecología y Desarrollo Rural (IRNAD), Sede Andina, Universidad Nacional de Río Negro (UNRN) and Consejo \\ Nacional de Investigaciones Científicas y Técnicas (CONICET), Mitre 630, CP 8400, San Carlos de Bariloche, Río Negro, Argentina
}

\section{A R T I C L E I N F O}

\section{Keywords:}

Bee response traits

Agricultural intensity

Availability resource

Above ground nesting

Solitary bees

Landscape complexity

\begin{abstract}
A B S T R A C T
Assessments of environmental drivers that regulate the functional composition of various organisms have become more frequent in the ecological literature, as this approach establishes a more direct connection between community structure and ecosystem functions. Bee response traits, such as sociality, body size, nest location, nest behaviour, and dietary specialization, have been reported in empirical studies that examine the role of land use intensity in functional diversity. However, empirical studies include different descriptors measured at different spatial scales, producing poor generalizations. Processes operating at different scales may have different effects depending on the response traits considered in the analysis. In this meta-analysis, we provide a quantitative assessment of the role that the structural complexity of habitats at local and landscape scales plays in the richness and abundance patterns of bees, considering different response traits. As indicated through this metaanalysis, the descriptors of structural complexity at the local scale explained more of the richness and abundance of bees with distinct response traits than the descriptors at the landscape scale. In addition, high management intensity has a negative effect on the different response traits. Below-ground nesting bees and social bees showed different abundance trends, which suggest a mechanism denominated 'response diversity'. This result suggests that the adoption of hybrid management strategies at the local scale could support the richness and abundance of different bees with distinct response traits in agroecosystems. These distinct response traits can be an important ecological pattern that contributes to the development of management strategies that maintain, in space and time, bees with distinct response traits. However, we should analyse the communities in terms of clusters of response traits, considering the possible synergies and trade-offs between these traits.
\end{abstract}

\section{Introduction}

Assessing the diversity of functional traits found in a particular biological community has been reported as a more direct way to establish a connection between biodiversity and ecosystem functioning than an approach focusing only on taxonomic diversity (Díaz and Cabido, 2001; Hooper et al., 2005; Díaz et al., 2007; Gagic et al., 2015). There are two dimensions related to functional traits: response and effect traits. The effect traits mediate the species contribution to ecosystem functioning and affect the species provision of ecosystem services (Wood et al., 2015). The presence or occurrence of a given species that possesses an important functional trait in a space-time snapshot may depend on environmental filters that can act in selecting that species (Díaz et al., 2007). However, the relative importance of each environmental driver depends on the response trait that is being evaluated, and the identification of relevant traits within a given context is a major challenge (Laliberte et al., 2010).

Functional response traits are traits that mediate the response of species abundance or occurrence in relation to environmental filters (Violle et al., 2007; Laliberte and Legendre, 2010), such as microclimate changes, vegetation complexity, landscape structure (Forrest et al., 2015; Le Feon et al., 2016; De Palma et al., 2015). Functional

\footnotetext{
* Corresponding author at: Departamento de Zoologia, Instituto de Biologia, Universidade Federal da Bahia, Barão de Jeremoabo Street, CEP 40170-115, Salvador, Bahia, Brazil.

E-mail addresses: jeferson.gabriel@gmail.com (J.G.d.E. Coutinho), lgaribaldi@unrn.edu.ar, garibald@agro.uba.ar (L.A. Garibaldi), blande.viana@gmail.com, blandefv@ufba.br (B.F.Viana).
} 
response traits are related to morphological, physiological or behavioural characteristics that define the distribution of organisms in space and time (Kremen and M'Gonigle, 2015; Gagic et al., 2015; Wood et al., 2015). Thus, functional composition in a community is determined by response traits (Ricotta and Moretti, 2011). For bees, the most important pollinator group (Klein et al., 2007), sociality, body size, nest location, nest behaviour and dietary specialization are the primary response traits used to explain community structure in agroecosystems (Rader et al., 2014; Ahrenfeldt et al., 2015; Warzecha et al., 2016), and some empirical studies have focused on mechanistic explanations to determine the influence of distinct environmental predictors on the diversity of these bees according to their response traits (Klein et al., 2003a; Le Feon et al., 2016). The evaluation of which response traits are more likely to explain the loss of species in scenarios, such as intensive farming regimes, can be an important step in promoting mitigation actions (Bartomeus et al., 2017). However, we lack general quantitative information on bee richness and abundance with different response traits in agroecosystems (but see Williams et al., 2010).

The studies that evaluated the diversity of bees according to their response traits in agroecosystems vary in terms of the spatial scale and the predictors used (Bommarco et al., 2010; Rader et al., 2014; BañosPicón et al., 2013). Ecological processes operating at different spatial scales complement each other in explaining the structure of a particular community, but the relative importance of these processes may vary according to the response trait considered in the analysis (Klein et al., 2008; Forrest et al., 2015; Martins et al., 2015; Ekroos et al., 2013). Ground nesting bees, for example, are strongly affected by management intensity of field crops, largely benefitting from open areas with low humidity content (Ngo et al., 2013). On the other hand, large social bees, which move small distances to forage and form small colonies, are more influenced by landscape heterogeneity (Ekroos et al., 2013), indicating that this group is more influenced by ecological processes at large spatial scales than local spatial scales (Aguirre-Gutiérrez et al., 2016). Light intensity best explains the abundance and richness of solitary bee species that nest on the ground in agroforestry systems in the tropical zone (Klein et al., 2003a; Klein et al., 2008). Other studies show that the richness of plant and flower abundance at a local scale are the predictors that best explain variation in richness and abundance of these bees (Albrecht et al., 2007), as well as the grassland coverage percentage in the landscape (Woodcock et al., 2013). These papers taken together show that the identity of these traits and the spatial scale approach are key aspects to understanding the influence of land use on the pattern of functional diversity in agroecosystems (Brittain et al., 2013; Aguirre-Gutiérrez et al., 2016). Quantitatively contrasting these different parameters and spatial scales of observation has not been well reported. In addition, explanations for the variation in the response of bees with different response traits have not been well defined.

In a meta-analysis, Bommarco et al. (2010) reviewed the trends of three functional groups in response to a reduction in habitat area. However, the study was based on a set of data collected for five different types of habitats in Central Europe, decreasing our ability to make broader generalizations, in addition to limiting the findings to the specificities of a restricted set of habitat types.

Through this study, we aim to provide general quantitative information about the different responses of bees, according to distinct response traits in relation to descriptors of habitat and landscape in agroecosystems, discussing the implications of the use of these traits to explain and predict the presence of bees in these systems. In this manner, we asked the following questions: i) At the local scale, to what degree does the intensity of management and structural aspects of the habitat consistently affect the richness and abundance of bees with different response traits? ii) At the landscape scale, to what degree does the landscape structure consistently affect the richness and abundance of bees with different response traits?

\section{Materials and methods}

\subsection{Literature search}

To conduct this meta-analysis, we followed the PRISMA protocol (Moher et al., 2009). To identify studies in the literature that address the influence of land use for agricultural and/or the context the surrounding landscape on the functional diversity of bees in agroecosystems, we conducted a search in the database Scopus and Web of Science using the following keyword combinations: [functional diversity AND bees AND agroecosystem] OR [trait* AND bees AND agroecosystem] OR [functional diversity AND bees AND landscape] OR [functional diversity AND bees AND landscape composition] OR [functional diversity AND bees AND landscape configuration] OR [pollinator* OR functional diversity OR bee OR bees OR apoidea OR pollinator*] AND [fragmentation OR landscape composition OR landscape configuration OR land use type OR landscape OR soil use].

\subsection{Protocol design}

Studies included in this meta-analysis had to meet the following criteria: presented a variable response to functional diversity of bees in agroecosystems or some functional trait measure not synthesized by an index; included replication; reported the sample size; presented the mean and standard deviation for the type of habitat used for data collection (for studies using categorical predictor variables), or presented some statistics such as correlation and regression coefficients (for continuous predictor variables), as the effect size was calculated from this information (see below).

The studies assessing the functional diversity of bees considered different approaches ranging from the measurement of a single trait (e.g., body size or dietary specialization) to studies that consider the synthesis of information on different functional traits through functional diversity indexes (Ricotta and Moretti, 2011). Only studies that considered individual response traits were used in this meta-analysis. Some authors reported no statistical values with non-significant results. These authors were contacted to avoid bias in the meta-analysis from studies that did not report non-significant results (Winfree et al., 2009).

\subsection{Grouping the data for meta-analysis: landscape and habitat descriptors}

Because of the different approaches considered in the studies, we divided the data into different groups for the quantitative evaluation of the effect size of each subgroup. The studies were separated according to the type of approach used in the predictor variables: landscape or habitat scale. We used two categories to encompass studies conducted at the landscape scale: the proportion of crop area and the proportion of non-crop area. Studies that evaluated the influence of natural or seminatural habitats (e.g., meadow in any proportion of radii from the point of sampling, proportion of home garden at a large scale, proportion of forest) at spatial scales wider than the habitat were included in the category "proportion of non-crop area". Studies that evaluated the influence of agriculture on the response variable were included in the "proportion of crop area". Accordingly, for many studies, the landscape structure was reported more than once, for example, measuring influence of crop and non-crop area. Therefore, "study" was included as a random variable in all mixed models (Shackelford et al., 2013) (see below). For studies that used more than one spatial scale to categorize the surrounding landscape, we chose the correlation coefficient with the greater value.

For the local scale, we used a similar approach such as described for the landscape scale. We reclassified the different measures used to describe structural complexity and the differences between agricultural intensities into three categories: structural complexity, resource availability and agricultural intensity. These categories reflect the different measures used in the original studies (empirical studies used in this 


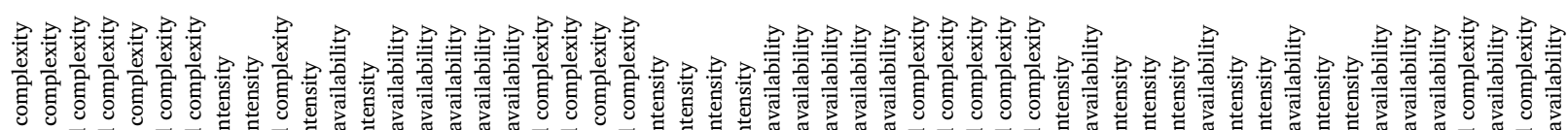

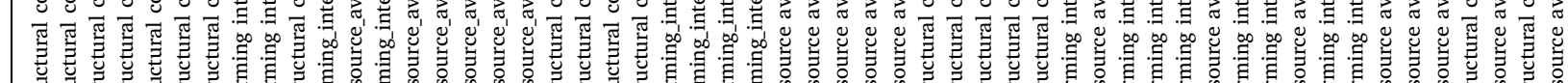

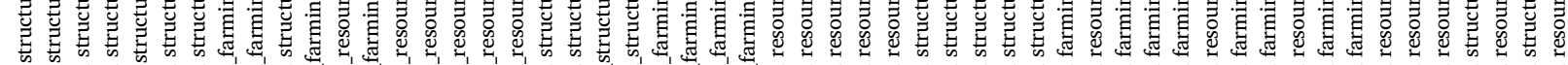

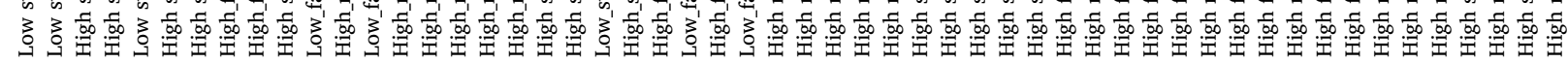

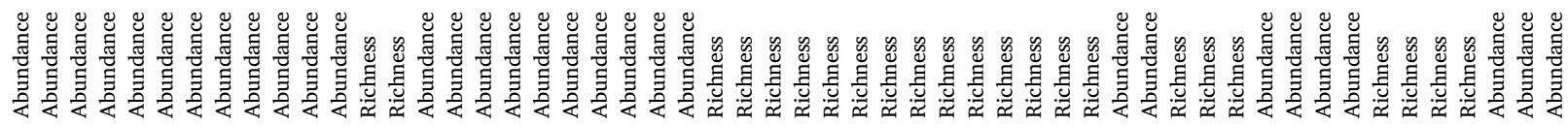

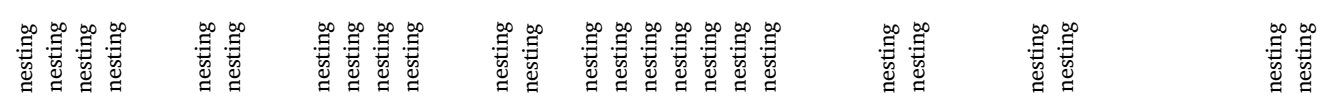

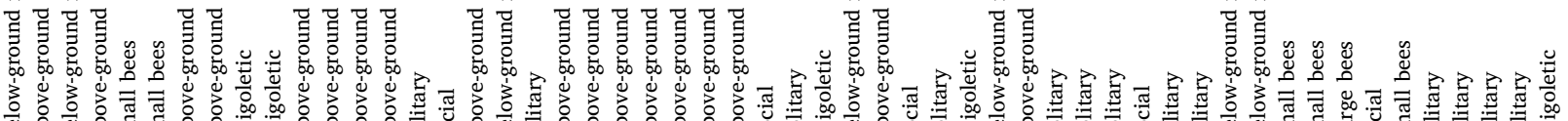

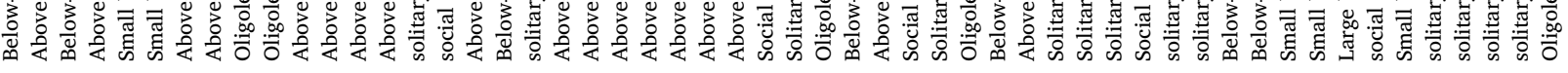




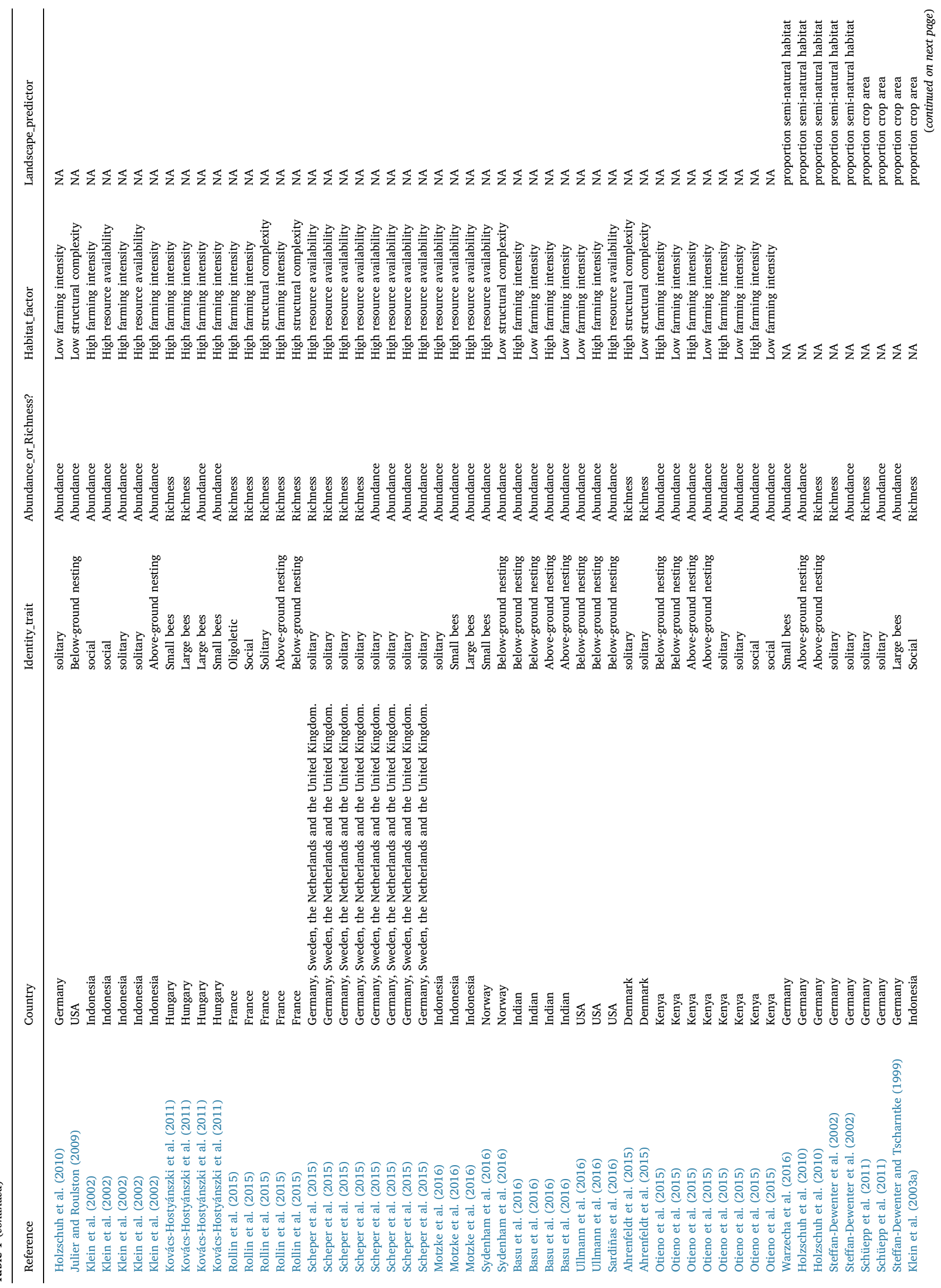




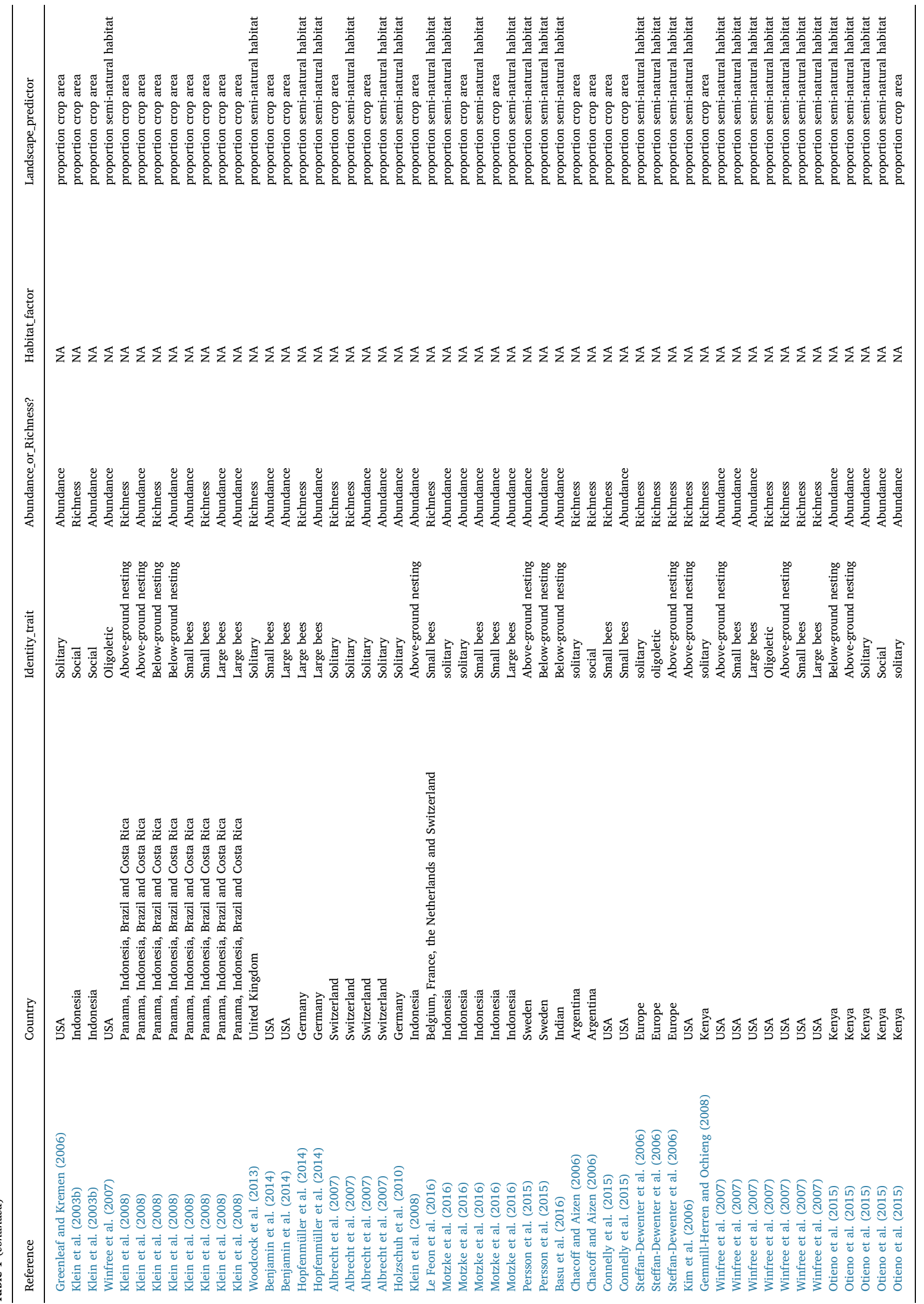


meta-analysis) and indicate the general trends in management intensity and the repercussions in terms of physical habitat structure and the availability resources (see Supplementary material for a complete list of variables in the original and used studies). Resource availability was a category used to group the studies that analysed the influence of floral resources on bee richness and abundance with a specific response trait (e.g., flower percentage). A good example of this category is Klein et al., 2003b, where the authors measured the percentage of cover of all noncoffee flowering plants (herbs) for each study field to estimate the pollen and nectar availability for the bees. In our meta-analysis, a large part of that individual study considers offering floral resources in the form of flower focal crops. Structural complexity was a descriptor used to group studies that evaluated attributes other than floral resources (e.g., light intensity, soil clay, semi-natural habitat in contrast with simpler habitats). For this proposal, Sydenham et al., 2016 performed bee sampling in three experimental areas. These areas included the cut areas, where all the trees were cut and left to decay in the plot; cut + remove, where all trees were cut and immediately removed from the plot; and uncut areas, where different levels of habitat structural complexity were generated. Agricultural intensity was a descriptor used to group studies that evaluated the response of bee richness or abundance in intensive farming systems (e.g., tillage, insecticide, and fertilizer use). One example can be seen in Ullmann et al. (2016). These authors sampled ground nesting bees in areas where shallow tilling occurs regularly in row crop fields irrigated with buried drip lines. Once grouping was complete, we evaluated the mean effect size and confidence interval, considering the richness and abundance of bees in relation to each response trait separately.

\subsection{Calculation of effect size}

To calculate the effect size of different predictors in our subset data for individual traits, we fitted the data set with generalized linear mixed models (GLMM). We evaluated the richness and abundance of the bees that had individual response traits in relation to the three descriptors above (first question), which were used as the fixed effect. 'Study' was included as a random variable effect. To answer our second question, we evaluated the influence of landscape structure (crop and non-crop area) as the fixed effect. The 'study' was used as the random effect.

We used the exact $p$-value or a statistical value such as $\mathrm{F}, \mathrm{t}, \mathrm{r}$ or $\mathrm{r}^{2}$, with degrees of freedom, to perform the conversion Fisher's Z, which is an effect size measure that standardizes and makes the studies comparable (Koricheva et al., 2013). If the study measured continuous variables to characterize the surrounding landscape of the sampling point, then we extracted the value of $t$ using a multiple regression, Pearson's $r$ for parametric correlations or $\rho$ of the nonparametric Spearman correlation (Winfree and Kremen, 2009). With these values obtained, the value of Z-Fisher was obtained by using the calculation "The Meta Analysis Calculator" available at http://www.lyonsmorris. $\mathrm{com} / \mathrm{mal}$ / (Taylor and Cooke, 2012). Using the Fisher-Z is very appropriate for the correlation data, where the use of $r$ becomes a skewed comparison $\left(z^{1 / 2}=\ln (1+r / 1-r)\right)$. The variance of this index is estimated by $\mathrm{v}=1$ /square-root ( $n$-3), being dependent only on the size of the sample (n) differing from the variance of the correlation coefficient, which depends on the sample size and the magnitude of the coefficient. We combined and modelled the effect sizes weighted by the inverse of its variance using mixed effect models in $R$, version 3.3.0 ( $R$ Development Core Team, 2010), and using the metafor package (Viechtbauer, 2010) through the rma.mv function (meta-multivariate analysis via/multilevel linear (mixed effects)). Data from F-tests with more than one degree of freedom were not considered in this metaanalysis.

\subsubsection{Publication bias}

The evaluation of possible bias in the publications was visually performed through a funnel plot (Matthias et al., 1997), which checks whether studies with small effect size distributions are absent from all published effect sizes. In the absence of bias in the literature, it is expected that studies with large effect sizes are plotted near the mean and that those with smaller effects will be distributed above and below the mean, creating a funnel-shaped figure. This assessment was performed by the funnel function in the metafor package.

\section{Results}

A total of 43 papers were used in this meta-analysis. From this total, 63 effect sizes were used at the landscape scale and 100 at the habitat scale (Table 1). Most studies were carried out in Central Europe (Germany with 10 studies and France with 3 studies), North America (USA with 9 studies) and Southeast Asia (Indonesia with 6 studies). All the other countries had 1 study (see Table 1). The analysis bias (funnel plot) indicated positive bias for some data sets (Figs. 3-5).

\subsection{Question 1: At the local scale, to what degree does the intensity of management and structural aspects of the habitat consistently affect the richness and abundance of bees with different response traits?}

Regarding our first question, we found 27 studies. Of which, 13 studies analysed nest location, 11 studies analysed sociality, 6 studies analysed body size, and 4 studies analysed dietary specialization. In the following section, we describe only the effect sizes with at least 4 studies; those obtained with lower sample sizes are shown in the figures for a general understanding of the available evidence and knowledge gaps. The abundance of above-ground nesting bees was negatively correlated with agricultural intensification (Fisher's Z-transformed $=0.86, p$-val $=0.01$; Fig. $1 \mathrm{~A}$ ). None of the other traits analysed showed a statistically significant relationship; however, except for solitary and large bees, all other traits tended to be negatively related to agricultural intensification (Fig. 1A). Structural complexity was negatively associated with the abundance of below-ground nesting bees (Fisher's Z-transformed $=-4.50, p$-val $=<.0001$, Fig. 1C) and had no relation to the other traits.

Regarding the number of species within each functional response trait, agricultural intensification was negatively associated with the richness of social bees (Fisher's Z-transformed $=-0.41, p$-val $=0.01$; Fig. 1D). Structural complexity was positively associated with the richness of social bees (Fisher's Z-transformed $=0.43, p$-val $=0.01$; Fig. 1F).

3.2. Question 2: At the landscape scale, to what degree does the landscape structure consistently affect the response of bees with different response traits?

Regarding our second question, we found 23 studies. Of which, 10 studies analysed sociality, 9 studies analysed body size, and 7 studies analysed nest location. Assessing the response of bees with different response traits to the landscape structure, the proportion of non-crop area was positively associated with the abundance (Fisher's Z-transformed $=1.05, p$-val $=0.01$; Fig. $2 \mathrm{~B}$ ) and richness of solitary bees (Fisher's Z-transformed $=1.54, p$-val $=0.0029$; Fig. $2 \mathrm{D}$ ) and had no related with the other traits. On the other hand, the proportion of crop area was negatively associated with the abundance (Fisher's Z-transformed $=-1.0485, p$-val $=0.01 ;$ Fig. $2 \mathrm{~A}$ ) and richness (Fisher's Ztransformed $=-1.54, p$-val $=<0.0001$; Fig. $2 \mathrm{C}$ ) of solitary bees. Some response traits used in this study (e.g., dietary specialization and body size) were not reported in studies using one of the categories of landscape descriptors we listed (Fig. 2).

\section{Discussion}

This meta-analysis has indicated a wide variety of responses in terms of richness and abundance of the bees in agroecosystems. We can 

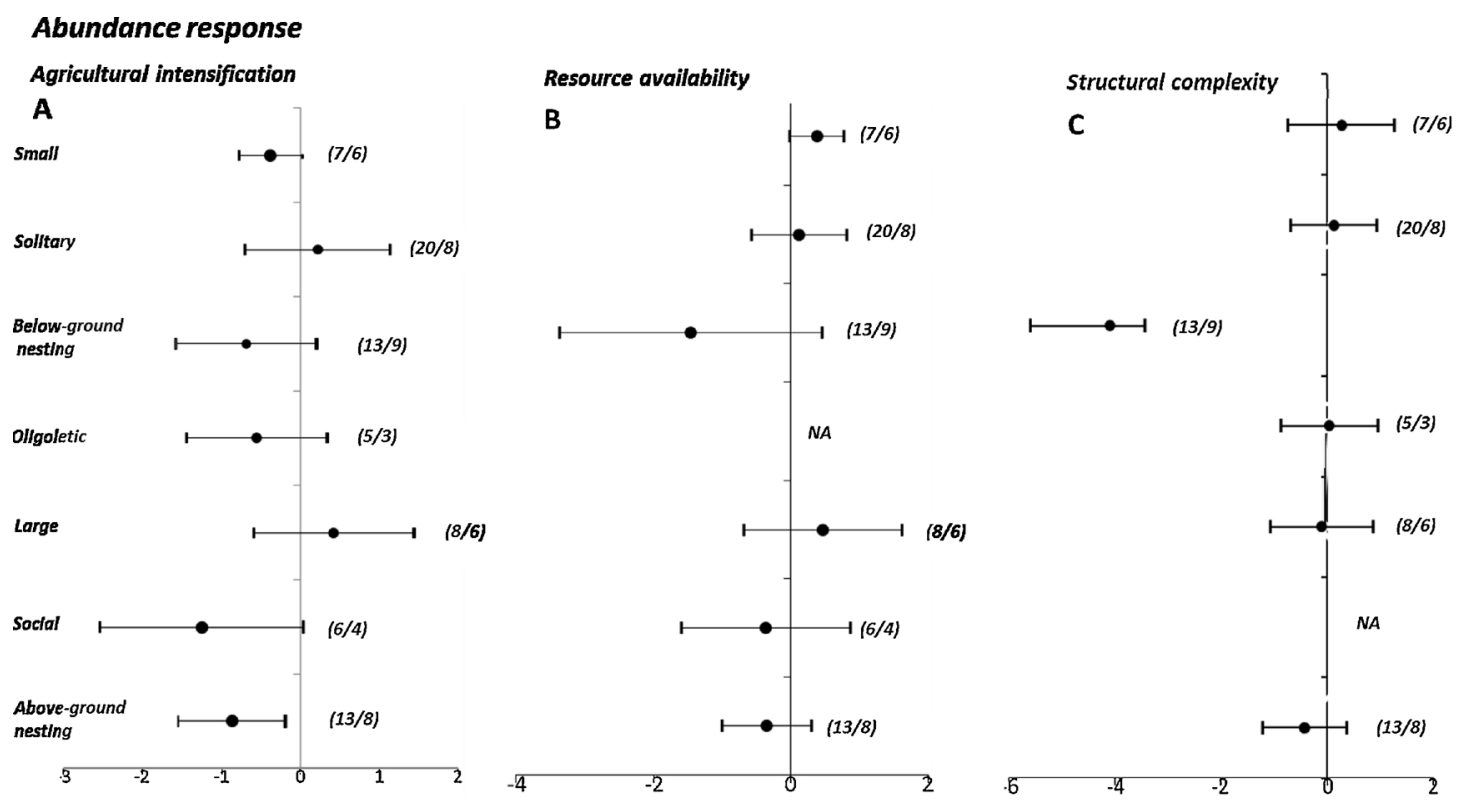

\section{Richness response}

\section{Agricultural intensification}

D

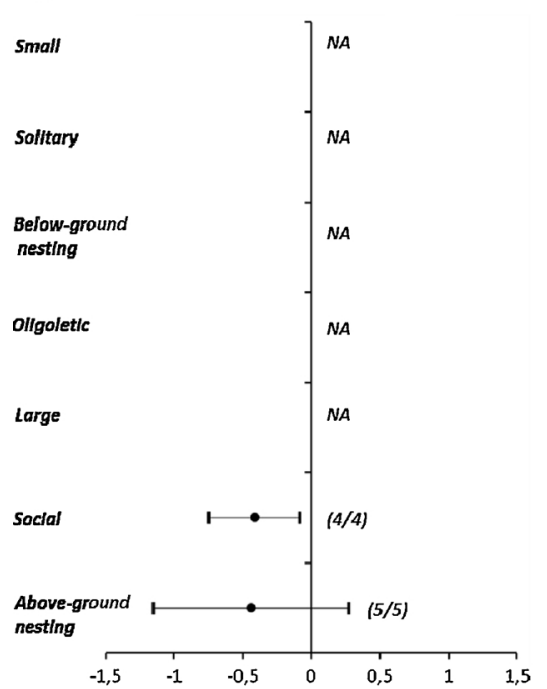

Resource availability

E

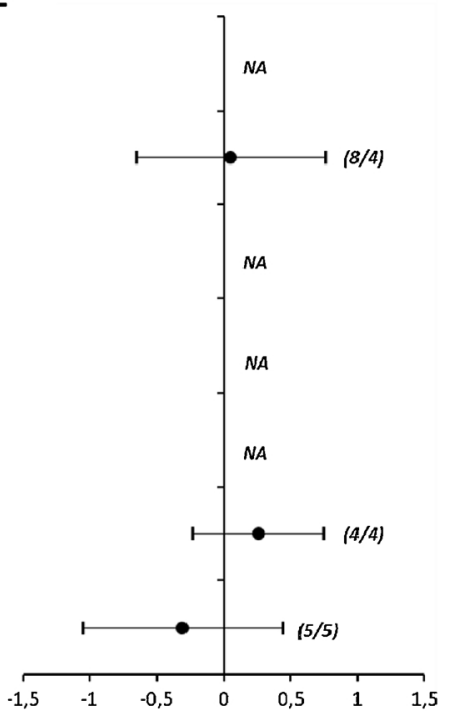

Structural complexity

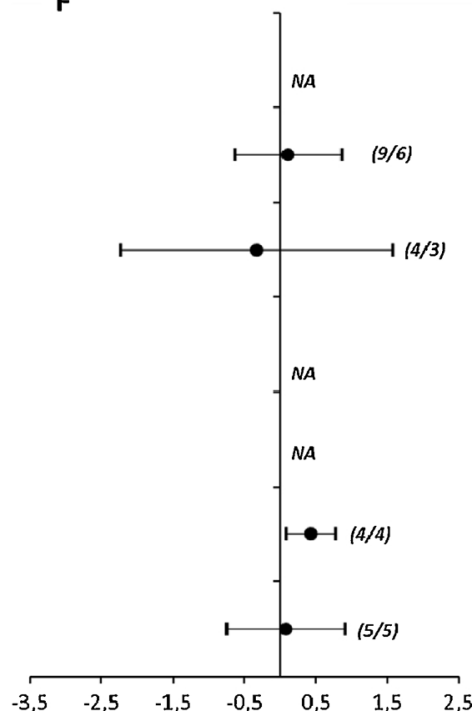

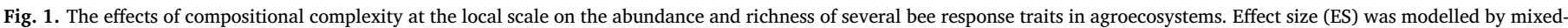

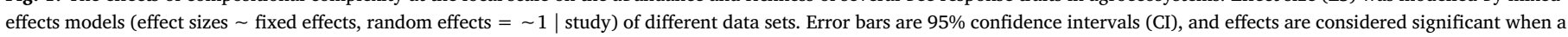
CI does not overlap with 0. Sample sizes (number of comparisons/number of individual studies) are given in parentheses. NA (not available).

attribute this variation to the different response traits used in the empirical studies and to the different ecological processes acting at multiple spatial scales. These results have many implications for the management of agricultural landscapes that aim to conserve bees' functional diversity.

Evaluation of the response of individual traits indicated that nest location and sociality, as also found by Williams et al., 2010, are important in assessing how intensive land use for agriculture on a local scale may affect the richness or abundance of these groups. The abundances of above-ground and below-ground nesting bees were negatively correlated with the intensification of agriculture, as well as the richness of social bees, showing us the importance of management intensity at a local scale. For decades, the intensification of agriculture has been a strategy used to increase food production (Bommarco et al.,
2012), but it has undermined the ability to maintain the availability of resources for several species, as well as to maintain characteristics in the habitat to ensure the requirements needed for biological diversity (Matson et al., 1997; Phalan et al., 2011). This agricultural intensification is characterized mainly by the presence of large fields of monocultures with external inputs that essentially consist of synthetic fertilizers and pesticides (Pretty, 2008) and associated with practices such as mowing and tillage. Management intensity promotes homogenization of habitat in large tracts of land, reducing the diversity of substrates for nesting (Gámez-Virués et al., 2015), such as bare soil (Klein et al., 2002) and distinct substrates above ground (Winfree et al., 2007; Williams et al., 2010; Kremen and M'Gonigle, 2015). Thus, bees with distinct response traits that have been negatively affected by the intensification of agriculture form a cluster of functional types 


\section{Abundance response}

\section{Proportion of crop area}

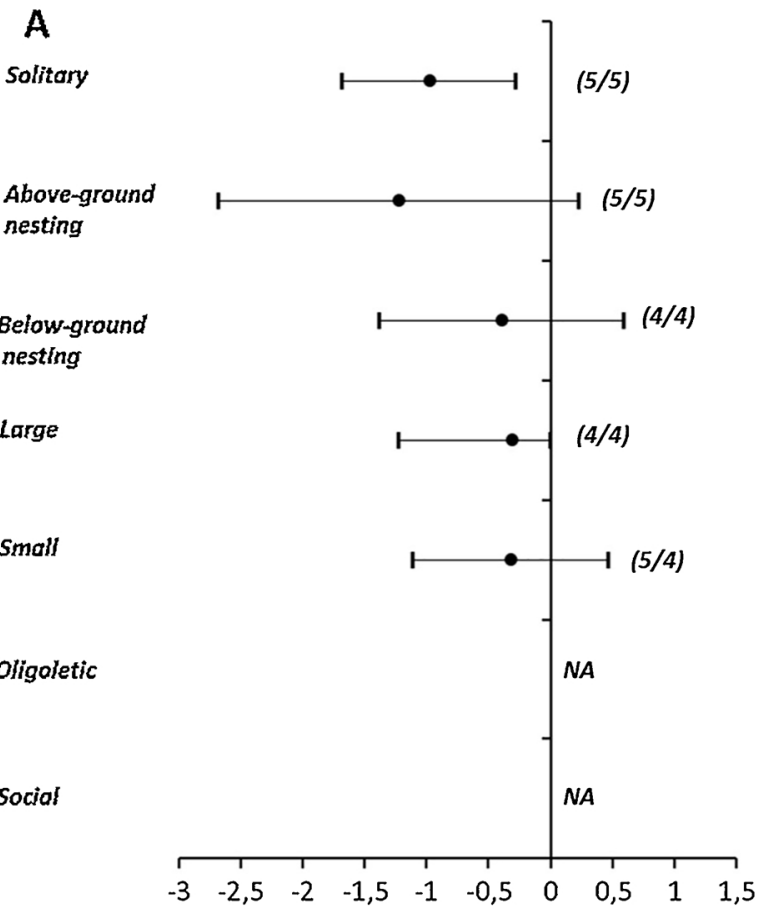

\section{Richness response}

\section{Proportion of crop area}

\section{c}

Solitary

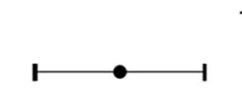

Above-ground

nesting

Below-ground

nesting

Lasge

Small

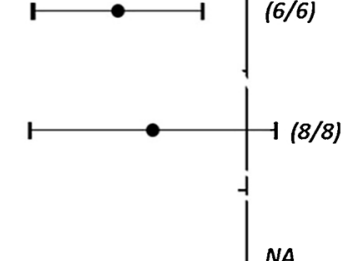

NA

NA

NA

oligoletic

Social

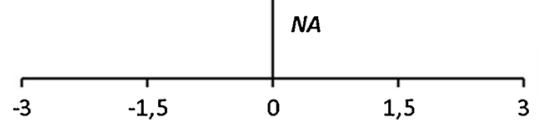

\section{Proportion of non-crop area}

B

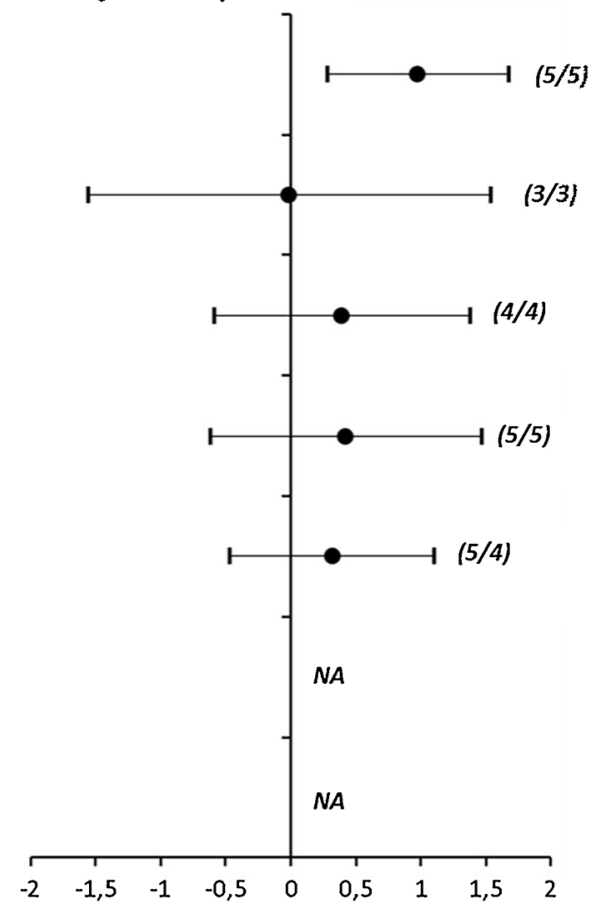

Proportion of non-crop areo

D

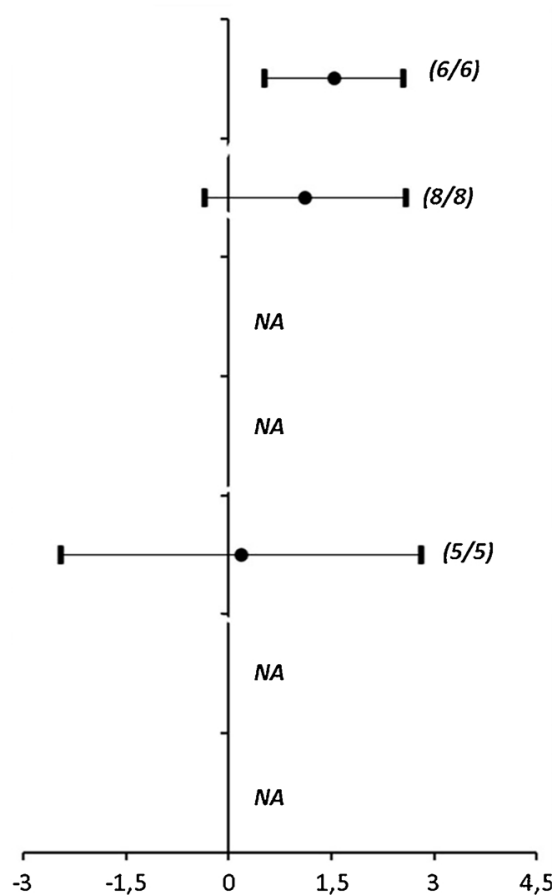

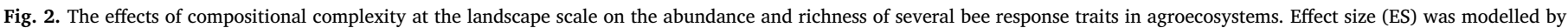

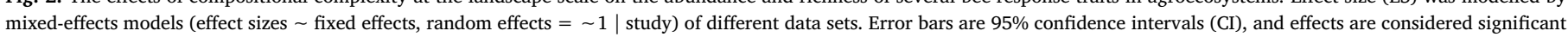
when a CI does not overlap with 0. Sample sizes (number of comparisons/number of individual studies) are given in parentheses. NA (not available). 

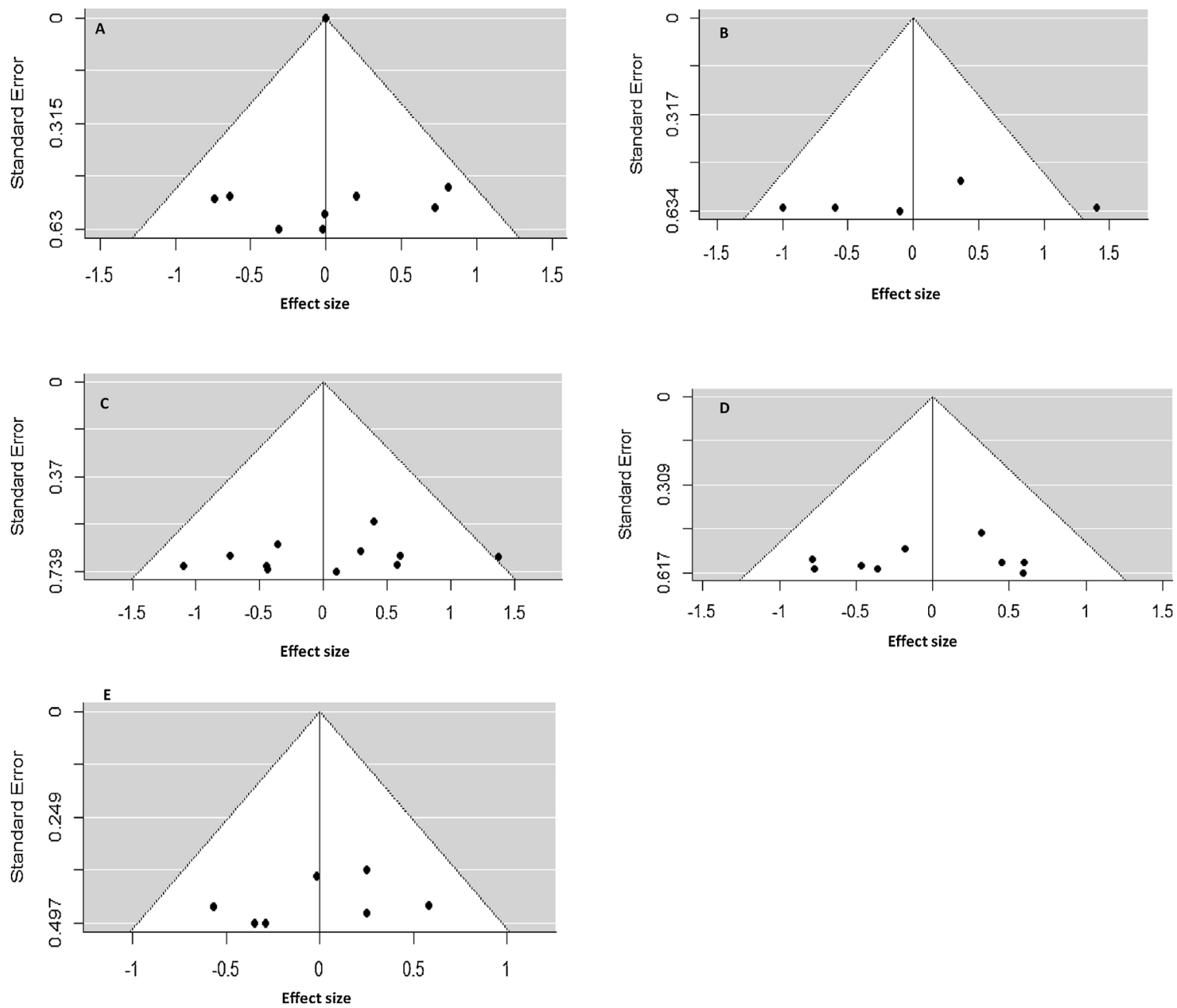

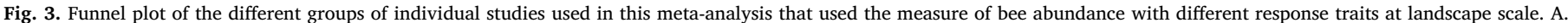

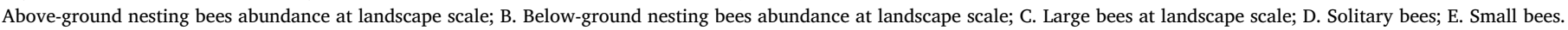

characterized by reduced abundance (above-ground nesting bees) or richness (social bees) where there is intensive management.

Structural complexity was negatively correlated with below-ground nesting bee abundance. One possible explanation for the results of our meta-analysis is that structural complexity, which is associated with vegetation density or richness of plants in the soil, is not important for this bee group such that they respond positively to bare soil (RogerEstrade et al., 2010). On the other hand, social bee richness is positively associated with structural complexity. This is an example of 'response diversity', which is defined as the diversity of responses to environmental change among species that contribute to the same ecosystem function (Elmqvist et al., 2003), which is pollination in this case. From the viewpoint of productivity in farming systems, with both groups of bees being important to maintaining the stability and magnitude of service, management strategies that offer a greater quantity and diversity of resources at the crop scale together with strategies that do not compact bare soil, for example, should be implemented to increase the probability of these bee groups co-occurring in large abundance and richness. This increase in resources on farms associated with alternative management practices such as less intense crop diversification, conservation tillage, and use of compost or organic matter (Pretty et al., 2006; Garibaldi et al., 2016) can lead to a process of ecological intensification (Bommarco et al., 2012) that increases the likelihood of maintaining a high abundance and richness of bees with distinct response traits at the local farm level farm and stability and magnitude of the service provided by them, since these bees can have distinct and complementary effect traits. Obviously, the impact on pollination service needs to be empirically study with a rigorous evaluation of which effect traits are related to these two large groups of bees in order to predict the possible impacts on pollination services in the systems in which they are inserted.

Regarding the landscape context, in a recent synthesis, a positive effect of landscape complexity on the richness and abundance of native bees was found, but this response was not checked considering different response traits (Shackelford et al., 2013). In other quantitative syntheses that evaluated the functional response of the bees to some landscape parameters or some disturbance caused by human activity, social species responded negatively to the isolation of natural habitats (Ricketts et al., 2008; Winfree et al., 2009; Williams et al., 2010) and positively to the proportion of natural habitats. Our findings point to the same trends found in these studies but in relation to solitary bees. Different data sets used in the studies by Ricketts et al., 2008; Winfree et al., 2009 and Williams et al., 2010 may help explain these differences. However, despite these differences, the presence of semi-natural habitats in the surrounding landscape of crops can offer various types of habitats that provide resources that are attractive to several species of solitary bees and contribute to the investment in the number of brood cells per nest (Holzschuh et al., 2010; Krauss et al., 2009), favouring the richness and abundance in crops near these environments. In addition, solitary native bees often have more specific requirements in terms of habitats (Steffan-Dewenter et al., 2002), which may contribute to the explanation of the negative relationship to the distance of natural habitats (increase in the proportion of crop areas) and the positive relationship to the increase in the proportion of non-agricultural area 

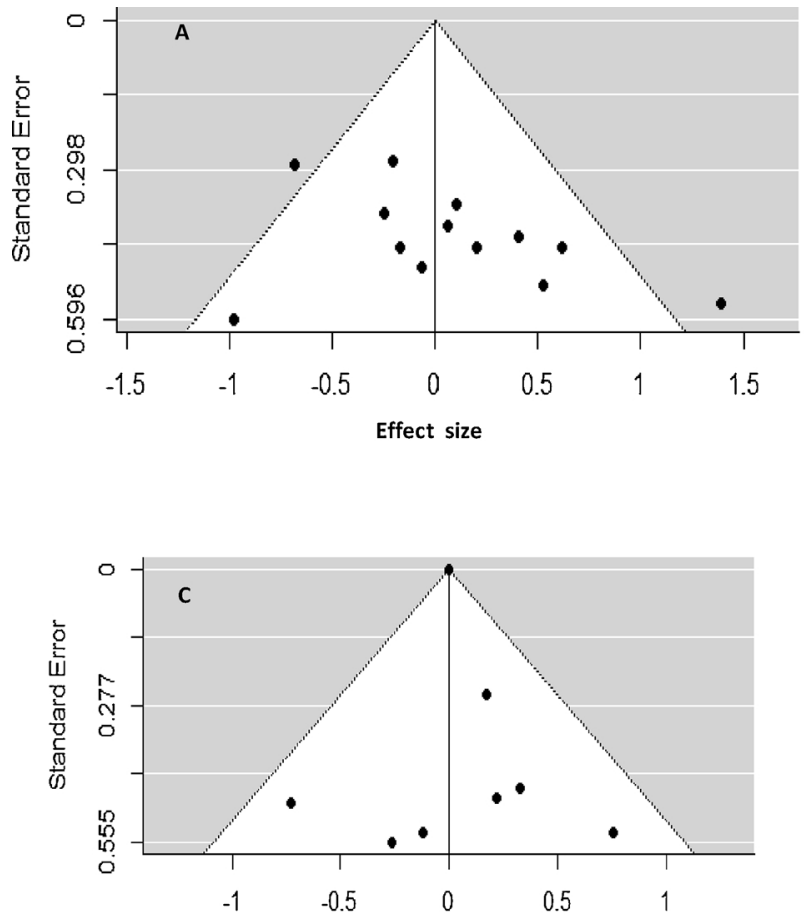

Effect size
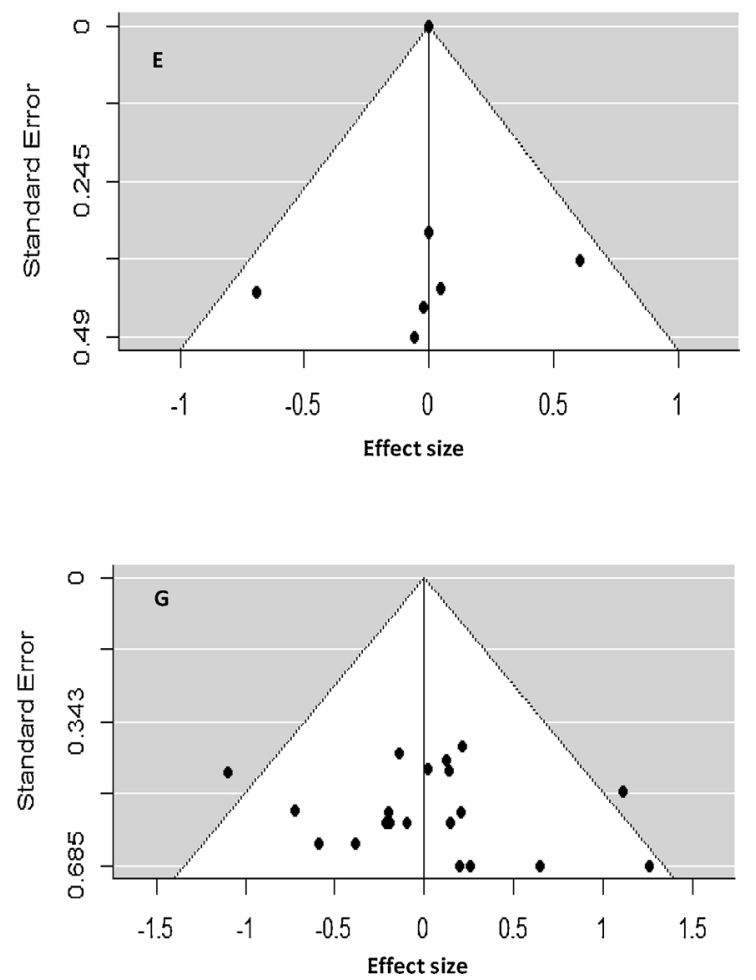
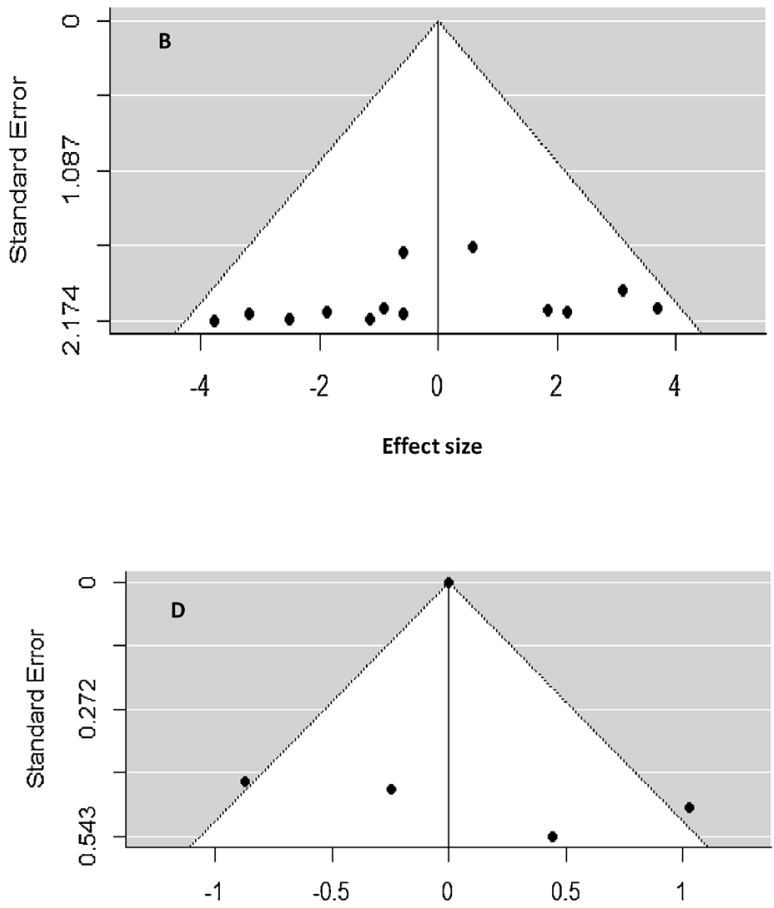

Effect size

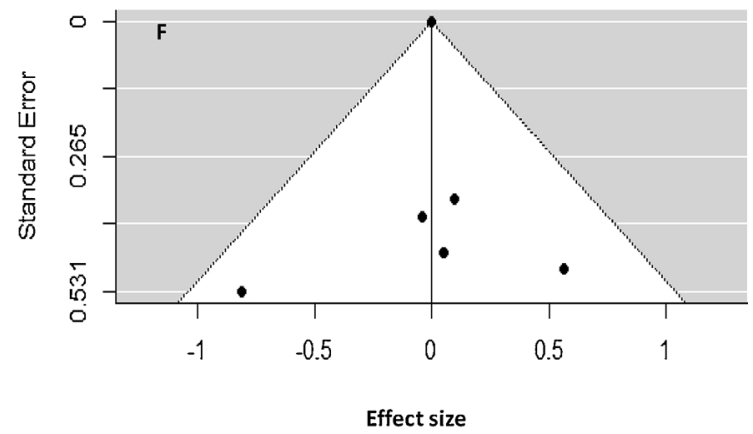

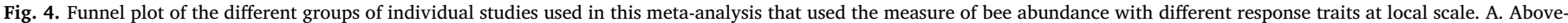

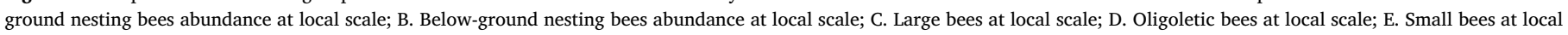
scale; F. Social bees at local scale; G. Solitary bees at local scale.

found in our meta-analysis. An important fact to consider is that $85 \%$ of the more than 20,000 known bee species are solitary, and little is known about most species and their population status (Freitas and Pereira, 2004). Our meta-analysis points to the importance of two important drivers that regulate both the richness and abundance of these bees in agroecosystems. The reduction in the proportion of natural areas is associated with the loss of alternative flora resources when there is no available resource in agricultural areas, in addition to providing a myriad of above-ground nesting sites (Kremen et al., 2004). Although we do not know the details of the requirements of most species of solitary bees, the maintenance of natural areas close to the crops can be a crucial strategy to increase the chance that these species 

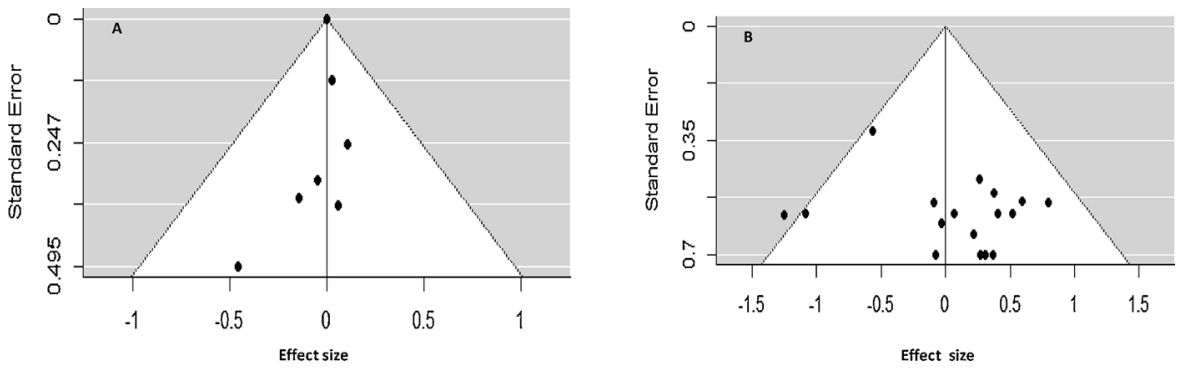

Fig. 5. Funnel plot of the different groups of individual studies used in this meta-analysis that used the measure of bee richness with different response traits at local scale. A. Aboveground nesting bees abundance at local scale; B. Solitary bees at local scale. remain in agroecosystems, bringing benefits in terms of the pollination of agricultural crops (Kremen et al., 2002).

The absence of temporal replicates is a recurrent problem in studies that aimed to compare richness and abundance responses of social and solitary bees to landscape changes (Kim et al., 2006), which can help us understand the difference among studies. In addition to the temporal dimension, landscape classifications are crucial to studies that consider their influence on biodiversity. A promising approach is in accordance with the concept of functional landscape heterogeneity (Fahrig et al., 2011), which assumes that any measure of heterogeneity should reflect the requirements of a species or a particular interest group, which makes sense from the ecological point of view.

Finally, one important aspect in the studies about functional diversity is to consider individual traits such as response variables, since the species are a "mosaic of traits" and may form the most relevant cluster of traits in the functional analysis of communities (Williams et al., 2010). Social small generalists were most strongly affected by the local descriptors of scale compared with the social large generalist bees (Hopfenmüller et al., 2014). However, there are few studies whose hypotheses and analyses are based on a "cluster of traits" contrasting different scenarios, which makes it impossible to use a quantitative synthesis for such approaches. Thus, we encourage authors to use the clusters of traits approach rather than individual traits. This type of information may be crucial, including the adoption of management practices that promote multi-functional landscapes (Ekroos et al., 2016) not only in terms of the composition and configuration of these landscapes but also in terms of the organisms that the landscapes contain. Despite the trends observed in the results of this meta-analysis, few studies have evaluated the response of bee richness and abundance according to the response traits presented here. The validation of the performance of these response traits within a set of traits can be a promising way to identify the groups most sensitive to intense soil management by agricultural practices.

\subsection{Conclusions}

This meta-analysis provided important general information on the role of intensification of agriculture and the surrounding landscape in the richness and abundance of bees, considering different functional response traits. The response of some functional traits in the same direction as the driver, such as above-ground nesting bees and social bees, indicates that certain clusters of traits are more affected by agricultural intensification than others. From these results, it was possible to verify response diversity between different response traits, since the abundance of below-ground nesting bees was negatively affected by the structural complexity of the crops, while the richness of social bees benefited from this increase. This result points to the need to think of hybrid management strategies that consider different types of soil cover if the intention is to maintain functional diversity for different response traits.

Considering the low number of papers included in each analysis of this meta-analysis and the way in which responses were included (individual response traits), we suggest that future studies test hypotheses about the influence of intensive soil use in relation to functional response groups (cluster of response traits). This approach can help us understand which groups are most sensitive as well as to understand the trade-offs between these response traits in modified contexts. In addition, we suggest that future studies address landscapes from a functional perspective (functional landscape heterogeneity) in order to understand the role that each type of coverage has on the dynamics of different functional groups of bees in agroecosystems, considering distinct response traits. Moreover, despite the statistical significance, the abundance of bees for all the response traits evaluated (except for solitary and large bees) showed a negative relationship with the intensification of agriculture. This result indicates that the adoption of management practices consistent with ecological intensification could reverse this scenario.

\section{Author contributions statement}

JGEC, BFV and LAG conceived the ideas and designed methodology; JGEC collected the data; JGEC analysed the data; and JGEC, BFV and LAG led in the writing of the manuscript. All authors contributed critically to the drafts and gave final approval for publication.

\section{Funding}

Activities for this study were supported by the National Council of Sciences and Technology (CNPq) [INCT IN-TREE grant number 465767/2014-1] and PVE Line 2 [grant number 407152/2013-0].

\section{Acknowledgements}

Lucas Alejandro Garibaldi is thankful for the financial support for the proposal of scientific, technological and/or innovation granted by the National Council of Sciences and Technology (CNPq) (Process number 407152/2013-0). Jeferson Gabriel da Encarnação Coutinho thanks the Instituto de Investigaciones en Recursos Naturales, Agroecología y Desarrollo Rural (IRNAD), Sede Andina, Universidad Nacional de Río Negro (UNRN), for the time to develop the study at the institution. Blandina Felipe Viana is thankful for financial support from Productivity in Research from CNPq. All authors thank the National Institute of Science and Technology in Interdisciplinary and Transdisciplinary Studies in Ecology and Evolution (INCT-IN-TREE).

\section{Appendix A. Supplementary data}

Supplementary data associated with this article can be found, in the online version, at https://doi.org/10.1016/j.agee.2017.12.025.

\section{References}

Aguirre-Gutiérrez, J., et al., 2016. Functional traits help to explain half-century long shifts in pollinator distributions. Nat. Publ. Gr. 1-13. http://dx.doi.org/10.1038/ srep 24451.

Ahrenfeldt, E.J., Klatt, B.K., Arildsen, J., Trandem, N., Andersson, G.K.S., Tscharntke, T., Smith, H.G., Sigsgaard, L., 2015. Pollinator communities in strawberry crops-variation at multiple spatial scales. Bull. Entomol. Res. 105 (4), 497-506. http://dx.doi. org/10.1017/S000748531500036X.

Albrecht, M., Duelli, P., Müller, C., Kleijn, D., Schmid, B., 2007. The Swiss agri- 
environment scheme enhances pollinator diversity and plant reproductive success in nearby intensively managed farmland. J. Appl. Ecol. 44, 813-822. http://dx.doi.org/ 10.1111/j.1365-2664.2007.01306.x.

Baños-Picón, L., Torres, F., Tormos, J., Gayubo, S.F., Asís, J.D., 2013. Comparison of two Mediterranean crop systems: polycrop favours trap-nesting solitary bees over monocrop. Basic Appl. Ecol. 14, 255-262. http://dx.doi.org/10.1016/j.baae.2012. 12.008.

Bartomeus, I., Cariveau, D.P., Harrison, T., Winfree, R., 2017. On the inconsistency of pollinator species traits for predicting either response to land-use change or functional contribution. Oikos. http://dx.doi.org/10.1111/oik.04507.

Basu, P., Parui, A.K., Chatterjee, S., Dutta, A., Chakraborty, P., Roberts, S., Smith, B., 2016. Scale dependent drivers of wild bee diversity in tropical heterogeneous agricultural landscapes. Ecol. Evol. 6, 6983-6992. http://dx.doi.org/10.1002/ece3.2360.

Benjamin, F.E., Reilly, J.R., Winfree, R., 2014. Pollinator body size mediates the scale at which land use drives crop pollination services. J. Appl. Ecol. 51, 440-449. http://dx. doi.org/10.1111/1365-2664.12198.

Bommarco, R., Biesmeijer, J.C., Meyer, B., Potts, S.G., Pöyry, J., Roberts, S.P.M., SteffanDewenter, I., Öckinger, E., 2010. Dispersal capacity and diet breadth modify the response of wild bees to habitat loss. Proc. R. Soc. B Biol. Sci. 277, 2075-2082. http://dx.doi.org/10.1098/rspb.2009.2221.

Bommarco, R., Marini, L., Vaissière, B.E., 2012. Insect pollination enhances seed yield, quality, and market value in oilseed rape. Oecologia 169, 1025-1032. http://dx.doi. org/10.1007/s00442-012-2271-6.

Brittain, C., Kremen, C., Klein, A.M., 2013. Biodiversity buffers pollination from changes in environmental conditions. Glob. Change Biol. 19, 540-547. http://dx.doi.org/10. $1111 /$ gcb.12043.

Chacoff, N.P., Aizen, M.A., 2006. Edge effects on flower-visiting insects in grapefruit plantations bordering premontane subtropical forest. J. Appl. Ecol. 43, 18-27. http:// dx.doi.org/10.1111/j.1365-2664.2005.01116.x.

Connelly, H., Poveda, K., Loeb, G., 2015. Landscape simplification decreases wild bee pollination services to strawberry. Agric. Ecosyst. Environ. 211, 51-56. http://dx.doi. org/10.1016/j.agee.2015.05.004.

Díaz, S., Cabido, M., 2001. Vive la différence: plant functional diversity matters to ecosystem processes. Trends Ecol. Evol. 16, 646-655. http://dx.doi.org/10.1016/S01695347(01)02283-2.

Díaz, S., Lavorel, S., Chapin, F.S., Tecco, P.A., Gurvich, D.E., Grigulis, K., 2007. Functional Diversity-at the crossroads between ecosystem functioning and environmental filters. In: Canadell, J., Pataki, D.E., Pitelka, L.F. (Eds.), Terrestrial Ecosystem in a Changing World. Springer, Berlin, pp. 79-91.

De Palma, A., Kuhlmann, M., Roberts, S.P.M., Potts, S.G., Börger, L., Hudson, L.N. Lysenko, I., Newbold, T., Purvis, A., 2015. Ecological traits affect the sensitivity of bees to land-use pressures in European agricultural landscapes. J. Appl. Ecol. 52, 1567-1577. http://dx.doi.org/10.1111/1365-2664.12524.

Ekroos, J., Rundlöf, M., Smith, H.G., 2013. Trait-dependent responses of flower-visiting insects to distance to semi-natural grasslands and landscape heterogeneity. Landsc. Ecol. 28, 1283-1292. http://dx.doi.org/10.1007/s10980-013-9864-2.

Ekroos, J., Ödman, A.M., Andersson, G.K.S., Birkhofer, K., Herbertsson, L., Klatt, B.K., Olsson, O., Olsson, P.A., Persson, A.S., Prentice, H.C., Rundlöf, M., Smith, H.G., 2016. Sparing land for biodiversity at multiple spatial scales. Front. Ecol. Evol. 3, 1-11. http://dx.doi.org/10.3389/fevo.2015.00145.

Elmqvist, T., Folke, C., Nystrom, M., Peterson, G., Bengtsson, J., Walker, B., Norberg, J., 2003. Response diversity, ecosystem change, and resilience. Front. Ecol. Environ. 1 (9), 488-494. http://dx.doi.org/10.2307/3868116.

Fahrig, L., Baudry, J., Brotons, L., Burel, F.G., Crist, T.O., Fuller, R.J., Sirami, C., Siriwardena, G.M., Martin, J.L., 2011. Functional landscape heterogeneity and animal biodiversity in agricultural landscapes. Ecol. Lett. 14, 101-112. http://dx.doi. org/10.1111/j.1461-0248.2010.01559.x.

Forrest, J.R.K., Thorp, R.W., Kremen, C., Williams, N.M., 2015. Contrasting patterns in species and functional-trait diversity of bees in an agricultural landscape. J. Appl. Ecol. 52, 706-715. http://dx.doi.org/10.1111/1365-2664.12433.

Freitas, Breno M., Pereira, J.O.P., 2004. 1st ed. Solitary Bees: Conservation, Rearing and Management for Pollination v. 1. Fortaleza, Imprensa Universitária da UFC, pp. 285.

Gámez-Virués, S., Perović, D.J., Gossner, M.M., Börschig, C., Blüthgen, N., de Jong, H., Simons, N.K., Klein, A.-M., Krauss, J., Maier, G., Scherber, C., Steckel, J., Rothenwöhrer, C., Steffan-Dewenter, I., Weiner, C.N., Weisser, W., Werner, M., Tscharntke, T., Westphal, C., 2015. Landscape simplification filters species traits and drives biotic homogenization. Nat. Commun. 6 (8568), 1-8. http://dx.doi.org/10. 1038/ncomms9568.

Gagic, V., Bartomeus, I., Jonsson, T., Taylor, A., Winqvist, C., Fischer, C., Slade, E.M. Steffan-Dewenter, I., Emmerson, M., Potts, S.G., Tscharntke, T., Weisser, W., Bommarco, R., 2015. Functional identity and diversity of animals predict ecosystem functioning better than species-based indices. Proc. R. Soc. B Biol. Sci. 282 (1801), 1-8. http://dx.doi.org/10.1098/rspb.2014.2620.

Garibaldi, L.A., Gemmill-Herren, B., D’Annolfo, R., Graeub, B.E., Cunningham, S.A., Breeze, T.D., 2016. Farming approaches for greater biodiversity, livelihoods, and food security. Trends Ecol. Evol. 32 (1), 68-80. http://dx.doi.org/10.1016/j.tree. 2016.10.001.

Gemmill-Herren, B., Ochieng, A.O., 2008. Role of native bees and natural habitats in eggplant (Solanum melongena) pollination in Kenya. Agric. Ecosyst. Environ. 127, 31-36. http://dx.doi.org/10.1016/j.agee.2008.02.002

Greenleaf, S.S., Kremen, C., 2006. Wild bee species increase tomato production and respond diVerently to surrounding land use in Northern California. Biol. Conserv. 133, 81-87. http://dx.doi.org/10.1016/j.biocon.2006.05.025.

Heard, M.S., Carvell, C., Carreck, N.L., Rothery, P., Osborne, J.L., Bourke, A.F.G., 2007. Landscape context not patch size determines bumble-bee density on flower mixtures sown for agri-environment schemes. Biol. Lett. 3, 638-641. http://dx.doi.org/10. 1098/rsbl.2007.0425

Holzschuh, A., Steffan-Dewenter, I., Tscharntke, T., 2010. How do landscape composition and configuration, organic farming and fallow strips affect the diversity of bees, wasps and their parasitoids? J. Anim. Ecol. 79, 491-500. http://dx.doi.org/10.1111/ j.1365-2656.2009.01642.x.

Hooper, D.U., Chapin III, F.S., Ewel, J.J., 2005. Effects of biodiversity on ecosystem functioning: a consensus of current knowledge. Ecol. Monogr. 75, 3-35. http://dx. doi.org/10.1890/04-0922.

Hopfenmüller, S., Steffan-Dewenter, I., Holzschuh, A., 2014. Trait-specific responses o wild bee communities to landscape composition, configuration and local factors. PLoS One 9 (8), 1-10. http://dx.doi.org/10.1371/journal.pone.0104439.

Jauker, B., Krauss, J., Jauker, F., Steffan-Dewenter, I., 2013. Linking life history traits to pollinator loss in fragmented calcareous grasslands. Landsc. Ecol. 28 (107). http://dx. doi.org/10.1007/s10980-012-9820-6.

Jha, S., Vandermeer, J., 2010. Impacts of coffee agroforestry management on tropical bee communities. Biol. Conserv. 143, 1423-1431. http://dx.doi.org/10.1016/j.biocon. 2010.03.017.

Julier, H.E., Roulston, T.H., 2009. Wild bee abundance and pollination service in cultivated pumpkins: farm management, nesting behavior and landscape effects. J. Econ. Entomol. 102 (2), 563-573.

Kim, J., Williams, N., Kremen, C., 2006. Effects of cultivation and proximity to natural habitat on ground-nesting native bees in california sunflower fields. J. Kansas Entomol. Soc. 79, 309-320. http://dx.doi.org/10.2317/0507.11.1.

Klein, A.-M., Steffan-Dewenter, I., Buchori, D., Tscharntke, T., 2002. Effects of land-use intensity in tropical agroforestry systems on coffee flower-visiting and trap-nesting bees and wasps. Conserv. Biol. 16, 1003-1014. http://dx.doi.org/10.1046/j.15231739.2002.00499.x.

Klein, A.-M., Steffan-Dewenter, I., Tscharntke, T., 2003a. Fruit set of highland coffee increases with the diversity of pollinating bees. Proc. Biol. Sci. 270, 955-961. http:// dx.doi.org/10.1098/rspb.2002.2306.

Klein, A.-M., Steffan-Dewenter, I., Tscharntke, T., 2003b. Pollination of Coffea canephora in relation to local and regional agroforestry management. J. Appl. Ecol. 40, 837-845. http://dx.doi.org/10.1046/j.1365-2664.2003.00847.x.

Klein, A.-M., Vaissière, B.E., Cane, J.H., Steffan-Dewenter, I., Cunningham, S.A., Kremen, C., Tscharntke, T., 2007. Importance of pollinators in changing landscapes for world crops. Proc. Biol. Sci. 274 (66), 95-96. http://dx.doi.org/10.1098/rspb.2006.3721. (191)

Klein, A.M., Cunningham, S.A., Bos, M., Steffan-Dewenter, I., 2008. Advances in pollinator ecology from tropical plantation crops. Ecology 89, 935-943. http://dx.doi. org/10.1890/07-0088.1.

Koricheva, J., Gurevitch, J., Mengersen, K. (Eds.), 2013. Handbook of Meta-Analysis in Ecology and Evolution. Princeton University Press, Princeton and Oxford.

Kovács-Hostyánszki, A., Batáry, P., Báldi, A., 2011. Local and landscape effects on bee communities of Hungarian winter cereal fields. Agric. For. Entomol. 13, 59-66. http://dx.doi.org/10.1111/j.1461-9563.2010.00498.x.

Krauss, J., Alfert, T., Steffan-Dewenter, I., 2009. Habitat area but not habitat age determines wild bee richness in limestone quarries. J. Appl. Ecol. 46, 194-202. http:// dx.doi.org/10.1111/j.1365-2664.2008.01582.x.

Kremen, C., M'Gonigle, L.K., 2015. Small-scale restoration in intensive agricultural landscapes supports more specialized and less mobile pollinator species. J. Appl. Ecol. 52, 602-610. http://dx.doi.org/10.1111/1365-2664.12418.

Kremen, C., Williams, N.M., Thorp, R.W., 2002. Crop pollination from native bees at risk from agricultural intensification. Proc. Natl. Acad. Sci. U. S. A. 99, 16812-16816. http://dx.doi.org/10.1073/pnas.262413599.

Kremen, C., Williams, N.M., Bugg, R.L., Fay, J.P., Thorp, R.W., 2004. The area requirements of an ecosystem service: crop pollination by native bee communities in California. Ecol. Lett. 7, 1109-1119. http://dx.doi.org/10.1111/j.1461-0248.2004 00662.x.

Laliberte, E., Legendre, P., 2010. A distance-based framework for measuring from multiple traits functional diversity. Ecology 91, 299-305. http://dx.doi.org/10.1890/082244.1.

Laliberte, E., Wells, J.A., DeClerck, F., Metcalfe, D.J., Catterall, C.P., Queiroz, C., Aubin, I., Bonser, S.P., Ding, Y., Fraterrigo, J.M., McNamara, S., 2010. Land-use intensification reduces functional redundancy and response diversity in plant communities. Ecol. Lett. 13 (1), 76-86.

Le Feon, V., Poggio, S.L., Torretta, J.P., Bertrand, C., Molina, G.A.R., Burel, F., Baudry, J., Ghersa, C.M., 2016. Diversity and life-history traits of wild bees (Insecta: hymenoptera) in intensive agricultural landscapes in the Rolling Pampa, Argentina. J. Nat Hist. 50, 1175-1196. http://dx.doi.org/10.1080/00222933.2015.1113315.

Martins, K.T., Gonzalez, A., Lechowicz, M.J., 2015. Pollination services are mediated by bee functional diversity and landscape context. Agric. Ecosyst. Environ. 200, 12-20. http://dx.doi.org/10.1016/j.agee.2014.10.018.

Matson, P.A., Parton, W.J., Power, A.G., Swift, M.J., 1997. Agricultural intensification and ecosystem properties. Science 277, 504-550.

Matthias, E., Davey, S.G., Martin, S., Christoph, M., 1997. Bias in meta-analysis detected by a simple, graphical test. BMJ 315, 619. http://dx.doi.org/10.1136/bmj.315.7109. 629.

Moher, D., Liberati, A., Tetzlaff, J., Altman, D.G., 2009. Preferred reporting items for systematic reviews and meta-analyses: the PRISMA statement. PLoS Med. 6 , e1000097. http://dx.doi.org/10.1371/journal.pmed.1000097.

Motzke, I., Klein, A., Saleh, S., Wanger, T.C., Tscharntke, T., 2016. Habitat management on multiple spatial scales can enhance bee pollination and crop yield in tropical homegardens. Agric. Ecosyst. Environ. 223, 144-151. http://dx.doi.org/10.1016/j. agee.2016.03.001.

Ngo, H., Gibbs, J., Griswold, T., Packer, L., 2013. Evaluating bee (Hymenoptera: apoidea) diversity using Malaise traps in coffee landscapes of Costa Rica. Can. Entomol. 145 
(4), 435-453. http://dx.doi.org/10.4039/tce.2013.16.

Otieno, M., Sidhu, C.S., Woodcock, B.A., Wilby, A., Vogiatzakis, I.N., Mauchline, A.L., Gikungu, M.W., Potts, S.G., 2015. Local and landscape effects on bee functional guilds in pigeon pea crops in Kenya. J. Insect. Conserv. 19, 647-658. http://dx.doi. org/10.1007/s10841-015-9788-Z.

Persson, A.S., Rundlöf, M., Clough, Y., Smith, H.G., 2015. Bumble bees show trait-dependent vulnerability to landscape simplification. Biodivers. Conserv. 24, 3469. http://dx.doi.org/10.1007/s10531-015-1008-3.

Phalan, B., Onial, M., Balmford, A., Green, R.E., 2011. Reconciling food production and. Science 333, 1289-1291. http://dx.doi.org/10.1126/science.1208742.

Pisanty, G., Mandelik, Y., 2015. Profiling crop pollinators: life history traits predict habitat use and crop visitation by Mediterranean wild bees. Ecol. Appl. 25, 742-752. http://dx.doi.org/10.1890/14-0910.1.

Pretty, J.N., Noble, D., Bossio, D., Dixon, J., Hine, R.E., Penning de Vries, F.W.T., Morison, J.I.L., 2006. Resource-Conserving agriculture increases yields in developing countries. Environ. Sci. Technol. 40, 1114-1119. http://dx.doi.org/10.1021/ es051670d.

Pretty, J., 2008. Agricultural sustainability: concepts, principles and evidence. Philos Trans. R. Soc. B Biol. Sci. 363, 447-465. http://dx.doi.org/10.1098/rstb.2007.2163.

Rader, R., Bartomeus, I., Tylianakis, J.M., Laliberté, E., 2014. The winners and losers of land use intensification: pollinator community disassembly is non-random and alters functional diversity. Divers. Distrib. 20, 908-917. http://dx.doi.org/10.1111/ddi. 12221.

R Development Core Team, 2010. R: A Language and Environment for Statistical Computing. R Foundation for Statistical Computing, Vienna, Austria. ISBN 3-90005107-0, URL http://www.R-project.org.

Ricketts, T.H., Regetz, J., Steffan-Dewenter, I., Cunningham, S.A., Kremen, C., Bogdanski, A., Gemmill-Herren, B., Greenleaf, S.S., Klein, A.M., Mayfield, M.M., Morandin, L.A., Ochieng', A., Viana, B.F., 2008. Landscape effects on crop pollination services: are there general patterns? Ecol. Lett. 11, 499-515. http://dx.doi.org/10.1111/j.14610248.2008.01157.x.

Ricotta, C., Moretti, M., 2011. CWM and Rao's quadratic diversity: a unified framework for functional ecology. Oecologia 167, 181-188. http://dx.doi.org/10.1007/s00442011-1965-5.

Roger-Estrade, J., Anger, C., Bertrand, M., Richard, G., 2010. Tillage and soil ecology: partners for sustainable agriculture. Soil Tillage Res. 111 (1), 33-40. http://dx.doi. org /10.1016/j.still.2010.08.010.

Rollin, O., Bretagnolle, V., Fortel, L., Guilbaud, L., Henry, M., 2015. Habitat, spatial and temporal drivers of diversity patterns in a wild bee assemblage. Biodivers. Conserv. 24, 1195-1214. http://dx.doi.org/10.1007/s10531-014-0852-x.

Sardiñas, H.S., Tom, K., Ponisio, L.C., et al., 2016. Sunflower (Helianthus annuus) pollination in Californian's Central Valley is limited by native bee nest site location. Ecol. Appl. 26, 438-447. http://dx.doi.org/10.1890/15-0033.

Scheper, J., Bommarco, R., Holzschuh, A, Potts, S.G., Riedinger, V, Roberts, S.P.M., Rundlöf, M., Smith, H.G., Steffan-Dewenter, I., Wickens, J.B., Wickens, V.J., Kleijn, D., 2015. Local and landscape-level floral resources explain effects of wildflower strips on wild bees across four European countries. J. Appl. Ecol. 52, 1165-1175. http://dx.doi.org/10.1111/1365-2664.12479.

Schüepp, C., Herrmann, J.D., Herzog, F., Schmidt-Entling, M.H., 2011. Differential effects of habitat isolation and landscape composition on wasps, bees, and their enemies. Oecologia 165 (3), 713-721. http://dx.doi.org/10.1007/s00442-010-1746-6.

Shackelford, G., Steward, P.R., Benton, T.G., Kunin, W.E., Potts, S.G., Biesmeijer, J.C.,
Sait, S.M., 2013. Comparison of pollinators and natural enemies: a meta-analysis of landscape and local effects on abundance and richness in crops. Biol. Rev. 88, 1002-1021. http://dx.doi.org/10.1111/brv.12040.

Steffan-Dewenter, I., Tscharntke, T., 1999. Effects of habitat isolation on pollinator communities and seed set. Oecologia 121, 432. http://dx.doi.org/10.1007/ s004420050949.

Steffan-Dewenter, I., Nzenberg, U.M., Rger, C.B., Thies, C., Tscharntke, T., 2002. Scaledependent effects of landscape context on three pollinator guilds. Ecology 83, 1421-1432. http://dx.doi.org/10.1890/0012-9658(2002)083[1421:SDEOLC]2.0. $\mathrm{CO} 2$.

Steffan-Dewenter, I., Klein, A.M., Alfert, T., Gaebele, V., Tscharntke, T., 2006. Bee diversity and plant-pollinator interactions in fragmented landscapes. In: Waser, N.M., Ollerton, J. (Eds.), Specialization and Generalization in Plant-Pollinator Interactions. Chicago Press, Chicago, IL, pp. 387-408.

Sydenham, M.A.K., Moe, S.R., Stanescu-Yadav, D.N., Totland, Ø., Eldegard, K., 2016. The effects of habitat management on the species, phylogenetic and functional diversity of bees are modified by the environmental context. Ecol Evol 6, 961-973. http://dx. doi.org/10.1002/ece3.1963.

Taylor, M.K., Cooke, S.J., 2012. Meta-analyses of the effects of river flow on fish movement and activity. Environ. Rev. 20, 211-219. http://dx.doi.org/10.1139/A2012009.

Ullmann, K.S., Meisner, M.H., Williams, N.M., 2016. Impact of tillage on the crop pollinating, ground-nesting bee, Peponapis pruinosa in California. Agric. Ecosyst. Environ. 240-246. http://dx.doi.org/10.1016/j.agee.2016.08.002.

Viechtbauer, W., 2010. Conducting meta-analyses in $\mathrm{R}$ with the metafor package. J. Stat. Softw. 36, 1-48.

Violle, C., Navas, M.-L., Vile, D., Kazakou, E., Fortunel, C., Hummel, I., Garnier, E., 2007. Let the concept of trait be functional!. Oikos 116, 882-892. http://dx.doi.org/10. 1111/j.2007.0030-1299.15559.x.

Warzecha, D., Diekötter, T., Wolters, V., et al., 2016. Intraspecific body size increases with habitat fragmentation in wild bee pollinators. Landsc. Ecol. 31, 1449. http://dx. doi.org/10.1007/s10980-016-0349-y.

Williams, N.M., Crone, E.E., Roulston, T.H., Minckley, R.L., Packer, L., Potts, S.G., 2010 Ecological and life-history traits predict bee species responses to environmental disturbances. Biol. Conserv. 143, 2280-2291. http://dx.doi.org/10.1016/j.biocon. 2010.03.024.

Winfree, R., Kremen, C., 2009. Are ecosystem services stabilized by differences amon species? A test using crop pollination. Proc. Biol. Sci. 276, 229-237. http://dx.doi. org/10.1098/rspb.2008.0709.

Winfree, R., Griswold, T., Kremen, C., 2007. Effect of human disturbance on bee communities in a forested ecosystem. Conserv. Biol. 21, 213-223. http://dx.doi.org/10. 1111/j.1523-1739.2006.00574.x.

Winfree, R., Aguilar, R., Vazquez, D.P., LeBuhn, G., Aizen, M., 2009. A meta-analysis of bees' responses to anthropogenic disturbance. Ecology 90, 2068-2076.

Wood, S.A., Karp, D.S., DeClerck, F., Kremen, C., Naeem, S., Palm, C.A., 2015. Functional traits in agriculture: agrobiodiversity and ecosystem services. Trends Ecol. Evol. 30, 531-539. http://dx.doi.org/10.1016/j.tree.2015.06.013.

Woodcock, B.A., Edwards, M., Redhead, J., Meek, W.R., Nuttall, P., Falk, S., Nowakowski, M., Pywell, R.F., 2013. Crop flower visitation by honeybees, bumblebees and solitary bees: behavioural differences and diversity responses to landscape. Agric. Ecosyst. Environ. 171, 1-8. http://dx.doi.org/10.1016/j.agee.2013.03.005. 